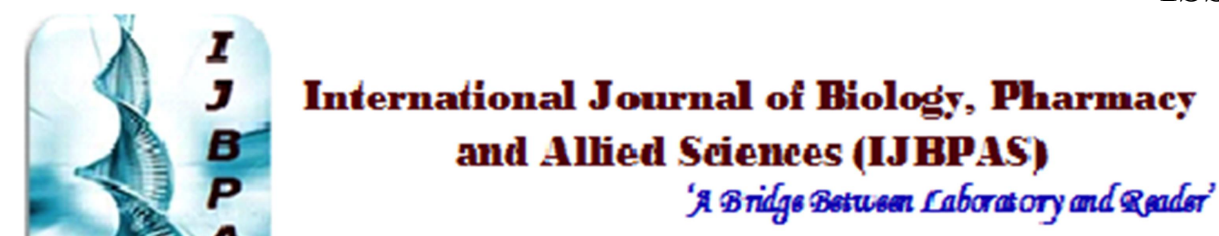

Www.ibpas.com

\title{
RAVAN - A DENTIST
}

\section{MESHRAM SA ${ }^{1 *}$ AND MESHRAM AA ${ }^{2}$}

1: Professor, Dept. of Dravyaguna, Parul Institute of Ayurveda \& Research

$$
\text { Limbda, Vadodara, Gujarat }
$$

2: Professor, Dept. of Anatomy, Parul Institute of Ayurveda, Limbda, Vadodara, Gujarat

*Corresponding Author: Meshram SA: E Mail: suwarna.meshram86231@paruluniversity.ac.in

Received 12 ${ }^{\text {th }}$ Dec. 2021; Revised $14^{\text {th }}$ Jan. 2022; Accepted $7^{\text {th }}$ Feb. 2022; Available online $5^{\text {th }}$ March 2022

https://doi.org/10.31032/IJBPAS/2022/11.3.1068

\begin{abstract}
Ravan was not only a powerful king but also a great author. He was a great Scholar in Ayurveda medicine. He was the one who wrote Arkaprakasha. Also he wrote Ravan Samhita which includes astrology, cosmetology, yantra, tantra, mantra vidya, kumartantra etc. (Names of Books written by Ravan)

The book Kumar Tantraya was written by him on the request of his pregnant wife Mandodari which contains treatment for infant diseases.

In Ravan Samhita he mentioned few dental treatments out of easily available medicinal plants. The beauty of his treatment is the simplest mode of administration.

To maintain oral hygiene in today's $21^{\text {st }}$ century is a real challenge as people are tend to eat more sweets, chocolates, soft drinks, hot drinks like tea and coffee. All such food habits are the major factors for oral diseases.

Alternative prevention and treatment option are more safe, effective, economical and practicable as many pathogens have developed resistance to currently used allopathic medicines. Commercially available allopathic medicines in the market can alter oral microflora and have undesirable side effects. Thus highlighting the importance of alternative medicines to maintain disease free oral health. Plant extracts and herbs used in Ayurveda are considered good alternatives to Modern medicine. A lot has been discussed about dentistry in Ayurveda by our Acharyas Charak and Sushruta. But very few of us are aware of the dental treatment told by Ravana. This text focuses on the use of easily available medicinal plants with simple mode of administration told by Ravan.
\end{abstract}

Keywords: Ravan Samhita, dentistry, Ayurveda, side effects, alternative medicine 


\section{INTRODUCTION-}

Oral diseases are a major health issues worldwide in $21^{\text {st }}$ century due to wrong food habbits and unhealthy lifestyle.

Alternative prevention and treatment option are more safe, effective, economical and practicable as many pathogens have developed resistance to currently used allopathic medicines. Commercially available allopathic medicines in the market can alter oral microflora and have undesirable side effects. Thus highlighting the importance of alternative medicines to maintain disease free oral health.

A lot has been discussed about dentistry in Ayurveda by our Acharyas Charak and Sushruta. But very few of us are aware of the dental treatment told by Ravana which is equally effective and economical due to easy availability and simple mode of administration.

Table 1: Uses of various herbs and their significant effect as told by Ravan in common dental diseases

\begin{tabular}{|c|c|c|c|c|}
\hline S. No. & Name of the Drug & Latin Name & Mode of Administration & Disorder \\
\hline 1 & Shigru gum & $\begin{array}{l}\text { Moringa olefera } \\
\text { Lam. }\end{array}$ & kept in mouth & Dental decay \\
\hline 2 & Ela and Lavanga Oil & & rubbed over tooth & Toothache,decay \\
\hline 3 & Shunthi powder-5gm & $\begin{array}{c}\text { Zinziber officinalis } \\
\text { Roscoe }\end{array}$ & taken with warm water & Toothache. \\
\hline 4 & Tankan and wax & Tankan & To be filled in cavity & Cavity. \\
\hline 5 & Musturd oil and salt & Brassica nigra $L$ & rubbed over tooth & Toothache. \\
\hline 6 & Turmeric rhizome & Curcuma longa $L$ & $\begin{array}{c}\text { Kept in between teeth and } \\
\text { sucked }\end{array}$ & Toothache. \\
\hline 7 & $\begin{array}{c}\text { Lemon juice and honey } \\
\text { each } 1 \text { part }\end{array}$ & $\begin{array}{l}\text { Citrus limon } \\
\text { (L).Osbec }\end{array}$ & Rubbed over gums & Bleeding gums, Pyorrhoea \\
\hline 8 & Lemon juice & $\begin{array}{l}\text { Citrus limon } \\
\text { (L).Osbec }\end{array}$ & Massaged on gums & Pyorrhoea \\
\hline 9 & $\begin{array}{l}\text { Pooga phala,Khadir saar } \\
\text { and leaves of Pippal- } \\
\text { Burnt and the ash mixed } \\
\text { with neela thotha }\end{array}$ & $\begin{array}{l}\text { Acacia arabica } \\
\text { Acacia catechu }\end{array}$ & Massaged over gums & Toothache. \\
\hline 10 & Ela & & Decoction gargaling & Toothache. \\
\hline 11 & $\begin{array}{l}\text { Lemon skin dried and } \\
\text { finely powdered }\end{array}$ & $\begin{array}{l}\text { Citrus lemon } \\
\text { (L).Osbec }\end{array}$ & $\begin{array}{c}\text { Brushed over teeth } 3 \text { to } 4 \\
\text { times a day. }\end{array}$ & $\begin{array}{l}\text { Clean,healthy teeth,bad } \\
\text { smell }\end{array}$ \\
\hline 12 & $\begin{array}{c}\text { Marich-1 to } 2 \text { gm,3 to } 4 \\
\text { leaves of Jambu or Guava }\end{array}$ & Piper longum $L$ & Decoction for gargaling & Toothache. \\
\hline 13 & $\begin{array}{c}20 \text { drpos of Rasona and } 1 \\
\text { tsp honey to be mixed }\end{array}$ & $\begin{array}{c}\text { Allium cepa } \\
L\end{array}$ & To be licked regularly & $\begin{array}{c}\text { Pyorrhoea,swollen gums, } \\
\text { toothache.bad smell }\end{array}$ \\
\hline 14 & $\begin{array}{l}\text { Hingu-5gm boiled in } 1 \\
\text { glass of water }\end{array}$ & Ferula foetida $L$ & Gargaling & Toothache. \\
\hline 15 & 25 gm Tila & Sesamum indicumL & Daily chew & Pyorrhoea,Healthy teeth \\
\hline 16 & $\begin{array}{c}\text { Flowers of Dadima and } \\
\text { Taruni-Dried and } \\
\text { powdered }\end{array}$ & $\begin{array}{c}\text { Punica granatum } \\
L\end{array}$ & Used for brushing teeth & Bleeding gums \\
\hline 17 & Sweet Dadima leaves & Punica granatum $L$ & Powedre used as Manjan & $\begin{array}{c}\text { Bleeding gums, Pyorrhoea, } \\
\text { swollen gums }\end{array}$ \\
\hline 18 & $\begin{array}{c}\text { Guava leaves or } \\
\text { Decoction mixed with } \\
\text { Fitkari } \\
\end{array}$ & Psidium guajava $L$ & $\begin{array}{l}\text { To be chewed } \\
\text { Gargaling }\end{array}$ & toothache. \\
\hline 19 & $\begin{array}{l}\text { Amra leaves and bark } \\
\text { taken in equal quantity } \\
\text { for decoction. }\end{array}$ & Mangifera indica $L$ & Gargaling & $\begin{array}{c}\text { For healthy teeth and } \\
\text { gums }\end{array}$ \\
\hline
\end{tabular}




\section{DISCUSSION-}

The effect of above mentioned drugs can be proved by doing clinical study.

Ela, Shunthi, Shigru, Mustard oil, Turmeric, Lemon, Marich, Rasona, Hingu, Tila being tikta, katu rasa and ushna viry removes kleda and pacifies vata and hence reduce Toothache and Toothdeacy.

Pooga phala, Khadira, Amra, Guava, Dadima leaves being Kashaya rasa does Rakta shodhana, kleda shoshana and ropana so useful in Bleeding gums and Pyorrhoea.

\section{CONCLUSION-}

Oral health is the mirror of the whole body and to maintain its health has become a bit difficult in today's era due to our wrong food habits and lifestyle. Allopathic medicines can only cure the dental problems but no medicines work for the healthy maintenance of oral cavity. On the contrary traditional herbal medicines work better over allopathic medicines
Now is the high time we should integrate professional dental treatment modalities and complementary alternative medical system to serve the best from each system to patients.

Ravan Samhita has told many easy and simple drugs available around us which can be used in common dental problems. So why not make use of them in or routine and avoid undesirable side effects of Allopathic medicines.

Clinical study can be the further scope of this review.

\section{REFERENCE-}

[1] 1.https://www.exoticindiaart.com/b ook/details/ravana-samhitaHAA168/ 20.10.20 time 13:04 IST

[2] 2.https://www.scribd.com/document /269499788/Ravana-Samhita

04.11.20 time 14:10 IST 